\title{
Iсторіографічні р0звідки
}

UDC: 930:(477)"12/15"

Andrii Blanutsa,

Candidate of Historical Sciences (Ph.D. in History), Senior Research Fellow, Institute of History of Ukraine National Academy of Sciences of Ukraine (Ukraine, Kyiv), andriiblanutsa@gmail.com, orcid.org/0000-0002-0849-8056

\section{HISTORIOGRAPHICAL VERSION AND INTERPRETATION OF PEREYASLAV LAND HISTORY IN THE SECOND HALF OF THE $13^{\text {TH }}-$ THE FIRST HALF OF THE $16^{\text {TH }}$ CENTURY}

The history of the Pereyaslav principality during the Kyivan Rus' period was fruitfully and thoroughly studied in the past and is being researched now by historians and archaeologists. The nearness of this historic land to the Kyiv gave rise to the attention of the Kyivan dukes, who elevated their sons in the Pereyaslav. And this, on the other hand, did not stimulate the creation of the local princely dynasty. And shortly (at the time of the struggle of the empires of the Golden Horde and the Grand Duchy of Lithuania for the Rus' lands and heritage) the absence of the local princely dynasty did not contribute to the preservation of a separate political and administrative unit. Since then, the Pereyaslav land had become a part of Kyiv land and, in this regard, is being 
studied by scientists. If a lot of archaeological and chronicle sources from the Rus' times preserved, but in the subsequent period, from the time of Pereyaslav land entry into the Golden Horde Empire (1240), their representativeness decreases sharply. In this regard, more problematic for historians was the "Lithuanian age" in the history of Pereyaslav land because of the minimal preservation of sources, both archaeological and written. Consequently, our research will allow answering several issues that remain unclear in the historiography of Pereyaslav land in the Tatar and Lithuanian times (second half of the 13. century - 1560ies). The main task is to study in what forms lasted life on the territory of Pereyaslav land, because of the absence of the comprehensive study on this topic.

The object of the research. This study deal with the political and social and economic history of Pereyaslav Land in the second half of the 13. century 1560-ies years.

The subject of the study consists in an attempt to analyze sources and facts concerning the matter, that Pereyaslav Land since the Mongol conquest has continued to exist within the new territorial unit of the Grand Duchy of Lithuania - Kyiv Land.

Therefore, the article aims to study issues concerning the continuation of Pereyaslav Land's political and social and economic history in the second half of the 13. century - 1560-ies.

To achieve the tasks set out in the work, we turned to the historical methods of analysis and synthesis, the empirical method, comparative analysis, and documentary analysis. The latter one is actively used during working with sources of Lithuanian metrica.

Keywords: Pereyaslav Land, Pereyaslav Principality, the Golden Horde, the Grand Duchy of Lithuania, historiography, historical artefacts.

Андрій Блануца, кандидат історичних наук, старший науковий співробітник, Інститут історії України Національної академії наук України

(Україна, Київ), andriiblanutsa@gmail.com, orcid.org/0000-0002-0849-8056

\section{ICTОРІОГРАФІЧНІ ВЕРСІЇ ТА ІНТЕРПРЕТАЦІЇ ІСТОРІЇ ПЕРЕЯСЛАВСЬКОЇ ЗЕМЛІ У ДРУГІЙ ПОЛОВИНІ XIII - ПЕРШІЙ ПОЛОВИНІ XVI ст.}

Про період історії Переяславського князівства в часи Київської Русі збереглося чимало археологічних та літописних джерел, що дозволило дослідникам відносно комфортно вивчати історію Переяславщини. Цього не можна сказати про наступний період історії, від часу входження Переяслава до складу імперії Золотої Орди (1240р.). Ще більш проблематичним для істориків став період "литовської доби" в історії Переяславської землі. Така ситуація склалася не тому, що цьому періоду бракувало дослідницької уваги, а внаслідок мінімальної збереженості дже- 
рел: як археологічних, так і писемних. Саме це і зумовило актуальність обраної теми, адже зосередження дослідницької уваги дозволить дати відповіді на низку питань, які залишаються нез'ясованими в історіографії Переяславської землі в татарські та литовські часи (друга половина XIII - 60-ті роки XVI cm.). Головним дослідницьким завданням $\epsilon$ відповідь на питання, у яких формах продовжувалося життя на території Переяславської землі, адже на сьогодні відсутнє комплексне дослідження з иієї теми.

Дане дослідження присвячено питанням політичної та соціальноекономічної історії Переяславської землі у другій половині XIII - 60-х років XVI cm. У рамках цієї проблеми будуть проаналізовані джерела та факти того, що Переяславська земля від часу монгольського завоювання продовжила існувати в межах нової територіально-адміністративної одиниці Великого князівства Литовського - Київської землі.

Відтак метою статті є дослідження комплексу питань тяглості політичної та соціально економічної історії Переяславської землі у другій половині XIII - 60-х років XVI cm.

Ключові слова: Переяславська земля, Переяславське князівство, Золота Орда, Велике князівство Литовське, історіографія, історичні артефакти.

The history of the Pereyaslav principality during the Kyivan Rus' period was fruitfully and thoroughly studied in the past and is being researched now by historians and archaeologists. The nearness of this historic land to the Kyiv gave rise to the attention of the Kyivan dukes, who elevated their sons in the Pereyaslav. And this, on the other hand, did not stimulate the creation of the local princely dynasty. And shortly (at the time of the struggle of the empires of the Golden Horde and the Grand Duchy of Lithuania for the Rus' lands and heritage) the absence of the local princely dynasty did not contribute to the preservation of a separate political and administrative unit. Since then, the Pereyaslav land had become a part of Kyiv land and, in this regard, is being studied by scientists. If a lot of archaeological and chronicle sources from the Rus' times preserved, but in the subsequent period, from the time of Pereyaslav land entry into the Golden Horde Empire (1240), their representativeness decreases sharply. In this regard, more problematic for historians was the "Lithuanian age" in the history of Pereyaslav land because of the minimal preservation of sources, both archaeological and written. Consequently, our research will allow answering several issues that remain unclear in the historiography of Pereyaslav land in the Tatar and Lithuanian times (second half of the 13. century - 1560ies). The main task is to study in what forms lasted life on the territory of Pereyaslav land, because of the absence of the comprehensive study on this topic.

There are many artefacts and chronicle about Rus' times of Pereyaslav land was preserved, which allowed relatively comfortably to study and write the history of this principality. What cannot be said about the next period, from the 
time when Pereyaslav land entered the Golden Horde empire (1240). However, even more, problematic for historians was the period of so-called "Lithuanian times" in the history of Pereyaslav land. This situation is caused not because this period was lacking research attention, but because of the minimal preservation of sources, both archaeological and written.

The poverty of the sources caused the corresponding trends in the historiography of the Pereyaslav land of the Lithuanian times. The chronicles of the after Rus' times dispose of even fragmentary mentions or reports about the political or any other life of Pereyaslav and its districts in the 14. -15. centuries. Only in the 19. century, the aggregate data (statistically, in the form of notes and reports) created by the amateur of antiquities were gaining popularity. The most valuable in these studies is the actual material or data grouped from the various sources about some areas of Ukraine. So, "Zapiski o Poltavskoy gubernii, sostavlennye v 1846" ("Notes") of N. Arandarenko is getting attention. «Notes» presented as a brief description of the "Pereyaslav district" (Arandarenko, 1852: 359-434) with the traditional for such historical research, topographical data, description of the industry, population and other materials. Describing the Pereyaslav N. Arandarenko mentioned the citadel of the upper town, which transformed into a castle during the Lithuanian period (Arandarenko, 1852: 372). Thus, here is a version of the existence of Lithuanian power in the city.

The "Notes" ' author also presents an interesting fact of the life and economic activity continuation of the one village, ruined by Mongols in 1239. It is about a small town, Zaruby, which was destroyed in 1239. However, part of the inhabitants, fleeing from death, managed to cross on the right bank of the river Dnipro. There, opposite the ruined Zaruby they founded a new settlement Zarubantsi (Arandarenko, 1852: 399). Thus, the life after the destruction of Pereyaslav land had continued and acquired new forms already in the Lithuanian times. N. Arandarenko noted that at the beginning of the 14. century Pereyaslav belonged to the Grand Duke Ioan Kalita, son of Olexander Nevsky. In 1320, the Lithuanian duke Gedimin defeated Pereyaslav duke Oleg, who, in an alliance with the Kyivan duke Stanislav, arrayed against the Lithuanians (Arandarenko, 1852: 400-401)1. Another important fact for our study is the date of 1514, which N. Arandarenko had mentioned in the context of social composition changing of Pereyaslav: " $\mathrm{Cr}$ 1514 года начинается важная епоха въ гражданскомъ быте Переяслава. До того времени коренными жителями этих месъ были Славяне; а съ этого года явилось здесь другое плем'я, козаки" (Arandarenko, 1852: 402). Of course, the evidence about Cossack's presence in Pereyaslav in 1514 needs to be clarified by the sources.

Mykhailo Hrushevsky paid some attention to the forms of government in the Pereyaslav land during Mongolian and post-Mongolian times both in a particular

${ }^{1}$ These data became controversial in the circles of professional historians. 
work (Hrushevs'kyj, 1891: 460-462) and the multi-volume series "The History of Ukraine-Rus'" (Hrushevs'kyj, 1905: 167-168, 170-172, 167-171). Hrushevsky, in particular, having supported his teacher Vladimir Antonovich, refuted the opinion of his predecessors about the total desolation and depopulation of the Dnieper region in the Mongolian times. In his "Essay of the Kyiv land from the death of Yaroslav to the end of the 14. century", M. Hrushevsky made a careful analysis of the second Lithuanian-Rus' chronicle concerning the conquest of Kyiv land by the Lithuanian duke Gedimin. Having argued with the points of view on this event with V. Antonovich and M. Dashkevich, M. Hrushevsky described the Gediminas campaign on Kyiv as a real, not a fantasy (Hrushevs'kyj, 1891: 473-484). The chronicle report itself stated, that Pereyaslav inhabitants sworn to Gedimin: " $U$ Перееславляне слышали, ижъ Кіевъ и пригородки Кіевскіе великому князю Гидымину, а господаръ ихъ князь Олегъ отъ великого князя Гидымина вбитъ, а они пріехавши, и подалися зъ городом служити великому князю Гидымину, а присягу свою на томъ дали" (quoted by: Hrushevs'kyj, 1891: 474-475). So, while the scientists have different views, we cannot completely reject the chronicle message like a real fact in the history of the Pereyaslav land of the early 14. century.

M. Lubavsky, in his work on the regional structure and local government in the GDL, dedicated a separate section of the book to Kyiv land. In particular, he described the administrative structure of the Kyiv province [voevodstvo] before the First Lithuanian Statute's adoption. Thus, in the territorial and administrative aspects, the Kyiv province consisted of the governorships [namestnichestvo] (the governors were in Mozyr, Bryagyn, Ovruch, Chernobyl, Zvyahol, Zhytomyr, and Cherkasy) and volosts [volost'] (Olevsk, Vyshgorod, Zavshska, Chudnovska, Osterska, and Putivlska) (Lyubavskiy, 1892: 235-248; Lyubavskiy, 1915: 95-102, 122132). M. Lubavsky considered the Pereyaslav land as a deserted territory of the Kyiv province and thus defined boundaries of Kyiv province as: "Киевская земля на левой стороне Днепра обнимала все бывшее Переяславское княжество и захвачивало южную часть земли Северской, т. е Посемье" (Lyubavskiy, 1892: 247).

M. Vladymyrsky-Budanov examined the Institute of local government in the GDL. In particular, for him, "Ukrainian" elderships [starostvo] in the $16^{\text {th }}$ century was the district of the state power, which gradually pushed off the significance of provinces. Headmen [starosta] concentrated in their hands the administrative and judicial power e corresponding territory. Such important elderships were not numerical. For example, there were six elderships in the Ukrainian lands of the GDL on the southern border (Bila Tserkva, Vinnytsia, Zhytomyr, Kaniv, Cherkassk, and also the Kyiv province, which had a character of eldership) and even three in Volhynia (Volodymyr, Kremenets, and Lutsk) (Vladimirskiy-Budanov, 1911: 52-53).

In the "History of Ukraine-Rus"" (in volume dedicated to the social and economic relations in Ukraine in the 14.-17. centuries) M. Hrushevsky explained the changes and weakening of Kyiv and neighboring cities (we mean the towns 
that provide a single trade complex, for example, Pereyaslav, Vyshgorod, Irpin, etc.) as a result of Tatar conquests and the pogroms. These actions "strongly cut the southern trade". Since then, the indigenous merchants have lost their positions in favour of foreign ones (Hrushevs'kyj, 1995: 4-8).

An exciting event in the scientific world was the publication of the book by P. Klepatsky "Essays on the history of the Kyiv land. Vol. I. The Lithuanian times" in 1912, Odesa. The author himself considered his work as a continuation of the well-known work of M. Hrushevsky (was analyzed above). Leading scientists (N. Yakovenko, L. Voitovich, O. Rusyna, etc.) spoke about its professionalism and high scientific level, while essays' reprinting to the $100^{\text {th }}$ anniversary to its first edition made the work more accessible to a wide range of scholars and historians (Klepatskij, 2007). For our research, the essays' author position on the problem of the Kyiv land entering into the political system of the GDL and the place of the Pereyaslav region in it his process is essential. Having carried out a detailed study, P. Klepatsky gave a lot of information on various aspects of the history of Kyiv region during the Lithuanian times. Meanwhile, there are very few references to Pereyaslav town and Pereyaslav land in his work. This limitation of mentions, on the one hand, points to the peripheral significance of the Pereyaslav region in the Lithuanian times, and on the other, it proves the poverty of sources on this topic. Despite this, the author, having described the activities of the Kyiv dukes Olelkoviches, gave a valuable fact concerning dukes' colonial policy, which was also directed to the ruined by Mongols Pereyaslav region. It is a fragment of the document which was published in one of the volumes of "Kievskaya starina" in 1896 (details below) about the lands granting to Olekhno Sokhnovich on the territory of the former Pereyaslav principality (Klepatskij, 2007: 76-77).

The work of A. Yablonovsky concerning the colonization of the Left Bank Ukraine of the 15. - 17. centuries deal with the place of Pereyaslav in the history of Kyiv land. The editors of "Kievskaya starina" published this study in 1896 (Yablonovskiy, 1896: 85-101) from the Yablonovskiy's article "Zadniprovia" from the "Geographical Dictionary". So, the scientist took the reference point for his essay from 1471, when the status of Kyiv land had changed from the local principality to the Kyiv province. In Yablonovsky's opinion, the northern part of the Kyiv province was occupied by the areas of the former Pereyaslav principality, because as he counted the Mongol invasion turned Pereyaslav region into wild fields similar to the neighboring Polovtsian deserts until the end of the 16 . century (Yablonovskiy, 1896: 85-101).

Nevertheless, A. Yablonovsky was the first to give an extract from the document, which was published in one of the volumes of "Kievskaya starina" in 1892, which ruined the myth concerning the total desolation of the Pereyaslav region in the Lithuanian times. It is an extract of the document dated February 1, 1455, in which Kyivan duke Olexander (Olel'ko) Volodymyrovich generously granted lands in the Pereyaslav region to landlord Olexandr Sokhnovich: «...че- 
тыре мпста бывшихъ укрппленій (городища: Старое на Днепре (Покалаурово), Бусурманское, Ярославское и Сальково) и четыре мпста бывшихъ не укрппленныхъ поселеній (селища: Булачинъ (ныне с. Ерковцы), Круглое, Сотниково за Каранью и Прощево)» (Yablonovskiy, 1896: 88).

Moreover, 0 . Yablonovsky added an interesting fact that the indicated lands in 1524 passed on to the gentry Lozki as a marriage portion. Further, he developed a theme about the intensification of colonization and new settlement arising in a steppe border at the end of the 15 . and early 16 . centuries. Thus, the scientist proved the fact of the colonization process restoration on the northwestern border of the ancient Pereyaslav principality, when the Grand Lithuanian duke Olexander Jagiellonian granted his nobleman considerable lands in the upper reaches of the Trubezh and Sopoy rivers in 1503 (Yablonovskiy, 1896: 88, 90). Olexander Yablonovsky concluded his study of the colonization processes in the Kyiv region as follows that «under the Lithuanian dukes the left bank of the Dnipro region ["Zadniprovya"] began to revive and populate by inhabitants, mainly from the upper reaches of the river Dnipro" (Yablonovskiy, 1896: 91). It should be noted, that the author introduces the concept of "Zadniprovya" into the scientific treatment and as a separate slogan this term was published in one of the volumes of the Polish "Słownik Geograficzny".

0 . Andriyashev widely raises the colonial subject in the history of Pereyaslav land. The author detailed the geographical boundaries of Pereyaslavl land before the Tatar times and in the 15. century in the broad sense of the territory that went under the Lithuanian rule - Zadnipryanshchyna (corresponding maps of this study are of great value for modern research). O. Andriyashev having studied colonization processes in the territory of Pereyaslav land during the 10. - 15 . centuries regularly address the current political situation, presents various points of view to controversial issues, tries to submit own objective position (Andriyashev, 1931: 1-29). The important thing is that in the so-called centuries of the endless desert (as scholars characterized Pereyaslav land mainly because of the lack of sources), as the author rightly notes, «there are too many names of settlements in Pereyaslav region which we know from the annals preserved to our days. For example, these are Pereyaslav, Pryluka, Pyryatin, Romen, and others. If the entire older population had died, then these names would not have been saved and would have died like the names of those nameless settlements that are so many now in the territory of the former Pereyaslav region» (Andriyashev, 1931:19-20). The author also considered that the political unit, under the name of Pereyaslav principality, disappeared forever, and the former lands of Pereyaslav region received a new name "Zadnipryanshchyna" (Andriyashev, 1931: 20 ). Thus, according to 0 . Andriyashev, Pereyaslav principality in political aspect have been transformed in a territorial and geographical sparsely settled area "Zadnipryanchshyna", which was under the formal rule of the Lithuanian dukes. 
Some changes in the studying of Rus' lands in the Tatar and Lithuanian times occurred in the 1990-ies and continue until today. Mostly, this is a separate study of narrow issues concerning the history of Kyiv land in the Tatar and Lithuanian days. Thus, the volume "Starozhytnosti Pivdennoji Rusi" (1993) based on historical and archeological workshop "Chernihiv and its surroundings in the 9. - 14. Centuries" (May of 1990) summarized these studies (Starozhytnosti Pivdennoyi Rusi, 1993). Concerning our topic, articles about Kyiv land and as its constituent part Pereyaslav land at the end of the 13. - 14. centuries are of interest. In particular, there is S. Belyaeva's study concerning the regional peculiarities of the agriculture development in the Middle Dnieper in the 10. - 14. Centuries (Belyayeva, 1993: 82-86). The author outlined that such factors as natural, social and economic, political, and ethnocultural influenced this development (Belyayeva, 1993: 82). The other scientist L. Ivanchenko drew attention to Poros' land, which was separated in volost' of the grand dukes' domain in the 12. century and started to play a significant role during the periods of political instability in Kyiv (Ivanchenko, 1993: 105-107). The theme of Poros' volost is essential for our study, first of all, because of the similarity of the territorial and administrative role and its significance with the Pereyaslav land in the 13. - 14. centuries.

In archaeology we find the essential points concerning the continuity of Pereyaslav land history in the Lithuanian times, what the studies of S. Belyaeva reflect. Thus, S. Belyaeva in a joint monograph with A. Kubyshev by the materials of settlements near the village Komarivka (Pereyaslav-Khmelnytskyi district, Kyiv region) gives a vivid description of the economic life continuation of the local population during the Tatar and Lithuanian times - the second half of the 13. - 15. centuries (Belyayeva, Kubyshev, 1995).

G. Kozubovsky gives exciting results concerning the economic development of the Kyiv land of the second half of the 14. century. Based on the research of coins, which the Kyiv duke Volodymyr Olgerdovich minted in the 1390-ies (one of such finds is the Borshchiv treasure, localized in Pereyaslav region), G. Kozubovsky concludes the high economic level of the Kyiv principality and the political status of Volodymyr Olgerdovich too (Kozubovs'kyj, 1993: 131-136). According to the author's observations, coins from Volodymyr Olgerdovich's treasure give grounds to talk about the dominant role of the Kyiv coins in the circulation on the considerable part of the Middle Dnipro in the 1390-ies. On the Kyiv region (including Pereyaslav land as its part) and the southern part of the Chernihiv region, the Kyiv dukes' coins practically displaced the Horde ones (Kozubovs'kyj, 1993: 131-136). Thus, the numismatic materials provide significant evidence of economic life and the development of political and administrative units in the context of the poverty of the written and act sources.

The collection "The Place and the Value of the Poros' land in the History of Ukraine (in the 9. - 17. centuries)" (Mistse i znachennia Porossia, 2007) raises essential scientific issues about the place and significance of another district of 
Kyiv region, i.e., Poros' land. According to M. Kvitnytsky, there were no clear boundaries and the system of territorial and administrative management in Poros' land (modern Korsun' region) in this period too. He also noticed the unique role of Poros' land in the Kyiv land line of defense, the so-called "Poros' line of defense" (Kvitnyts'kyj, 2007).

Petro Kulakovs'kyi examines the history of the Zvynyhorod district in the Lithuanian times. This region in the 14. - the first half of the 16. century like the Pereyaslav region suffered from the permanent destructive influences of nomadic hordes. Therefore, both contemporaries and researchers regarded it as a sparsely settled and ruined territory. However, according to P. Kulakovsky's studies, Zvynyhorod during the dukes Olelkoviches' reign remained as a Kyiv suburb. After the loss by Kyiv principality its separate status, Zvynyhorod district became relatively independent from the Kyiv governor. Because since that time the Lithuanian grand duke appointed the governors, but not the Kyiv governor ["voevo$\left.d a^{\prime \prime}\right]$ himself. Also, the economic decline of Zvynyhorod land became an additional factor that promoted weakening the connection with Kyiv (Kulakovs'kyj, 2015). Having followed V. Antonovych, P. Kulakovs'kyi noted the absence of boyars in general (that is noble stratum) in Zvynyhorod and Pereyaslav districts; both districts were devastated by the Tatars so much, that the dukes stopped to send there the governors (Kulakovs'kyj, 2015: 222; Antonovych, 1995).

Olena Rusyna has a significant accomplishment in the studying of Kyiv land history in Tatar times. As the researcher pointed out, was describing Ukraine in the political system of the Golden Horde, "there have also been more large-scale changes of political structure, as evidenced by changes in the macro toponomy of Ukrainian lands" (Rusyna, 2008: 62-63). In her opinion, the unknown from the old Rus' time concept of «Kyiv land» and "Siversk land" (Rusyna, 2008: 63) was established to replace the term "Kyiv land" in the sense of the political and geographical nomenclature (as the collective name of the Kyiv region, Pereyaslav region, and Chernihiv region). Since that time, Pereyaslav land in a terminological sense associated with the term "Kyiv land". In general, the Kyiv land history in the post-Mongol and Lithuanian times did not acquire the value in the studies of many generations of historians, which should belong to the key region, the nucleus, and centre of state-building processes in Ukraine. The processes of depopulation and "liquidation of the principality" and "the parallel Tatar administration formation and the Tatar population centres resulted in the development of the term "Tatar land", which had been turned out to the stable component of the ethnographic conceptions of the 14. - the 16. centuries" (Rusyna, 2005b: 24). Earlier M. Korinny stated the destruction of the state system, the cessation of the significant number of administrative centres and even principalities, such as Pereyaslav. There, after the Mongol conquest, according to the historian, neither the local Ruthenian dukes nor their governors are mentioned (Korinnyj, 1992). 
In her final work, O. Rusyna, relying on the works of V. Antonovich and M. Hrushevsky, rejected the theory of the continuous decline of Rus' after the Mongol invasion. In her opinion, it "caused a devastating blow to historical life in the Dnipro region, but did not stop its flow" (Rusyna, 1998: 21). Pereyaslav in the Tartar times continued to be a "pin" of Kyiv, and the absence of the Kyiv duke's dynasty in the second half of the 13. century led to the fact that these lands left without dukes (Rusina, 1998: 30).

0 . Rusyna also, on the example of the Putivl volosts of the Lithuanian period, showed a strong economic connection of this left bank region of the Kyiv province (Rusina, 1996; Rusina, 2005b: 114-136). In particular, she mentioned about stable profits flows to Kyiv from fourteens Putivl' volosts, and therefore the Kyiv nobility always kept these lands in their hands (Rusina, 2005b: 114-115).

According to 0. Pritsak's keen observation, the chronological period from the middle of the 13. century to 1440 remains the darkest in the history of the region (Pritsak, 1988). This point of view also shared Olena Rusina. The scientist, in particular, in "Studies on the History of Kyiv and the Kyiv land» noted that «the progress in the study, what is traditionally called the "Tatar" and "Lithuanian" times in the history of Kyiv region was rather insignificant" (Rusina, 2005b: 6).

An interesting observation concerning the political and administrative system and the management system of Pereyaslav land in the Tatar and Lithuanian times presents Yu. Mykhailuk in his monograph on the Southern part of Kyiv region in the 1360-ies and 1560-ies (Mykhaylyuk, 2011). In particular, the historian denies "a categorical judgment that the lands of the middle reach of the Dnipro left without dukes from the time of the Mongol invasion to the end of the 13. century". The author gives an example of the duke Yurij Porossian's reign in Poros as a real fact (Mykhaylyuk, 2011: 53-56).

The problem of "leaving without dukes" in the Middle Dnipro (Kyiv region and Pereyaslav region) in the second half of the 13. century as scientists noted, still has no an unambiguous algorithm for its ultimate solution. Moreover, the problem of administrative and territorial and also state subjection of these territories remains controversial. Thus, S. Tomashivsky and Y. Tereshchenko considered that the lands of the Middle Dnipro (Kyiv Region and Pereyaslav region) included into the Golden Horde and have become the Tartar provinces with the khan's representative ["baskak"] at the head (Tomashivs'kyy, 1919; Tereshchenko, 1996). However, the vast majority of scholars tend to think that "the Ruthenian lands did not enter directly into the ulus of the Juchid, but were in vassal dependence on the khan" (Mykhaylyuk, 2011: 48-49). Based on the analysis of scientists' points of view, chronicles and numismatic finds on the territory of the Middle Dnipro, G. Kozubovsky concluded the permanent rebirth of life in Pereyaslav region in the 14. Century (Kozubovs'kyj, 2012b; Kozubovs'kyj, 2012a; Kozubovs'kyj, 2015; Veremejchyk, Kozubovs'kyy, 2016; Kozubovs'kyj, 2016). 
Thus, scholars' particular research interest to the history of Pereyaslav land created the basis for studying the "dark" ages of Pereyaslavl region. Different points of view and interpretation of a few sources cause a lot of questions in the history of the Pereyaslav region of the second half of the 13. - the middle of the 16. century. At the same time, new archaeological finds and written sources in combination can result in a more detailed study of the stated topic.

(translated by Larysa Zherebtsova)

\section{BIBLIOGRAPHY}

Андріяшев О. Нарис історії колонізації Переяславської землі. Записки історико-філологічного відділу ВУАН. Київ, 1931, Кн. 26, 1-29.

Антонович В. Киев, его судьба и значение с XIV по XVI столетие (1362-1569). Моя сповідь: Вибрані історичні та публіцистичні твори. Київ, 1995, 558-561.

Арандаренко Н. Записки о Полтавской губернии, составленные в 1848 году: в 3-х ч. Полтава, 1852, ч. 3, 359-434.

Бєляєва С. О. Про регіональну специфіку розвитку сільського господарства Середнього Подніпров'я у X-XIV ст. Старожитності Південної Русі. Матеріали III історико-археологічного семінару "Чернігів і його округа в IX-XIII cm.". (Чернігів, 15-18 травня 1990 р.). Чернігів, 1993, 82-86.

Бєляєва С. О., Кубишев А. І. Поселення Дніпровського Лівобережжя X-XV cm. (за матеріалами поселень поблизу сіл Комарівка та Озаричі). Київ, 1995, 110.

Веремейчик О.М., Козубовський А. Г. Середньовічний монетний скарб із розкопок Любеча. Археологія. 2016, № 1, 64-69.

Владимирский-Буданов М. Заставное владение. Архив Юго-Западной России. Киев, 1911, ч. 8, т. VI, 52-53.

Грушевский М. Очерк истории Киевской земли от смерти Ярослава до конца $X I V$ столетия. Киев: Тип. Императорского Университета Св. Владимира В. И. Завадского, 1891, 460-462.

Грушевський М. С. Історія Украӥни-Руси: В 11 т., 12 кн. / Редкол.: П. С. Сохань (голова) та ін. Київ: Наук. думка, 1995. (Пам'ятки іст. думки України), т. VI, 4-8.

Грушевський М. Історія України-Руси. Львів, 1905, т. 3, 167-172.

Іванченко Л. І. Пороські князі. Старожитності Південної Русі. Матеріали III історико-археологічного семінару "Чернігів і його округа в IX-XIII cm.". (Чернігів, 15-18 травня 1990 р.). Чернігів, 1993, 105-107.

Квітницький М. Пороська захисна лінія: етапи формування та розвитку (у світлі писемних та археологічних джерел). Місце і значення Поросся 8 історії України (IX-XVII cm.): матеріали науково-практичної конферен- 
ції. 28 листопада 2007 р. / Редкол.: П. Я. Степенькіна (відп. ред.) та ін. Корсунь-Шевченківський, 2007, 17-50.

Клепатский П. Г. Очерки по истории земли Киевской: Литовский период. Біла Церква: Вид. О. В. Пшонківський, 2007, 480, карти.

Козубовський А.Г. До хронології карбування монет Володимира Ольгердовича (1362-1394). Археологія, 2016, № 4, 27-41.

Козубовський Г. Переяславська земля в XIV ст. Історико-географічні дослідження в Україні. Зб. наук. пр. 2012, число 12, 96-109.

Козубовський Г.А. Київське князівство при Володимирі Ольгердовичі за пам'ятками нумізматики. Старожитності Південної Русі. Матеріали III історико-археологічного семінару "Чернігів і його округа в IX-XIII cm.". (Чернігів, 15-18 травня 1990 р.). Чернігів, 1993, 131-136.

Козубовський Г.А. Дані нумізматики про торгівельні шляхи в Україні в середині XIV ст. Археологія, 2012, № 3, 75-82.

Козубовський Г.А. Про деякі економічні наслідки походів Гедиміна 20-х років XIV ст. Археологія, 2015, № 3, 33-43.

Коринный Н. Н. Переяславская земля: X - первая половина ХІІІ века. Киев, 1992, 67.

Кулаковський П. Звинигородський повіт у литовську добу. Ukraina Lithuaniса: студії з історії Великого князівства Литовського. Київ, т. III, 204-237.

Любавский М. К. Областное деление и местное управление Литовско-Русского государства ко времени издания первого Литовского статута. Москва, 1892, 235-248;

Любавский М. К. Очерк истории Литовско-Русского государства до Люблинской унии включительно. Москва, 1915, 95-102, 122-132.

Михайлюк Ю. Південна Київщина в 60-х рр. XIV - 60-х рp. XVI ст.: державне управління та громадське самоврядування. Черкаси: "Вертикаль", 2011, 348.

Місце і значення Поросся в історії України (IX-XIII cm.). матеріали науковопрактичної конференції. 28 листопада 2007 р. / Редкол.: П. Я. Степенькіна (відп. ред.) та ін. Корсунь-Шевченківський, 2007, 136.

Русина 0. Студії з історії Києва та Київської землі. Київ: Інститут історії України НАН України, 2005, 348.

Русина О. Путивльські волості XV - початку XVII ст. Записки НТШ. Львів, 1996, т. 231, 367-378.

Русина О. Путивльські волості XV - початку XVII ст. Студії з історії Києва та Київської землі. Київ, 2005, 114-136.

Русина О. В. Татарська й литовська доба в історії України. Політична система для України: історичний досвід і вік клики сучасності / О. Г. Аркуша, С. О. Біла, В. Ф. Верстюк та ін..; Гол. ред. В. М. Литвин. Київ: Ніка-Центр, 2008, 57-82.

Русина О. В. Україна під татарами і Литвою. Київ, Видавничий дім "Альтернативи", 1998, 420. 
Старожитності Південної Русі. Матеріали ІІІ історико-археологічного семінару «Чернігів і його округа в IX-XIII cm.". (Чернігів, 15-18 травня 1990 р.). Чернігів, 1993, 184.

Томашівський С. Українська історія. Старинні і середні віки. Львів, 1919, ч. 1, 99.

Терещенко Ю. І. Україна і європейський світ: нарис історії від утворення старокиївської держави до кінці XVI cm. Київ, 1996, 173.

Яблоновский А. Левобережная Украина в XV-XVIII ст. Киевская старина, 1896, т. LIII, 85-101.

Pritsak, 1988 - Pritsak, O. (1988). The Pre-Ashkenazic Jews of Eastern Europe in Relation to the Khzars, the Rus' and the Lithuanians. Ukrainian-Jewish Relations in Historical Perspective. Edmonton, 1988, 14.

\section{REFERENCES}

Andriyashev, 1931 - Andriyashev, O. (1931). Narys istoriyi kolonizatsiyi Pereyaslavs'koyi zemli. Zapysky istoryko-filolohichnoho viddilu VUAN (Vol. 26.). Kyiv, 1-29. [in Ukrainian].

Antonovych, 1995 - Antonovych, V. (1995). Kiev, eho sud'ba i znachenie s XIV po XVI stoletie (1362-1569). Moya spovid': Vybrani istorychni ta publitsystychni tvory. Kyiv, 558-561. [in Russian].

Arandarenko, 1852 - Arandarenko, N. (1852). Zapiski o Poltavskoy gubernii, sostavlennyye v 1848 godu: v 3 kn. (pt. 3), Poltava, 359-434. [in Russian].

Belyayeva, 1993 - Byelyayeva, S. (1993) Pro rehional'nu spetsyfiku rozvytku sil's'koho hospodarstva Seredn'oho Podniprov"ya u X-XIV st. Starozhytnosti Pivdennoyi Rusi. Proceedings of the 3rd Historical and archeological Workshop "Chernihiv i yoho okruha v IX-XIII st.". Chernihiv, 82-86. [in Ukrainian].

Belyayeva, Kubyshev, 1995 - Byelyayeva, S., Kubyshev A. (1995) Poselennya Dniprovs'koho Livoberezhzhya X-XV st. (za materialamy poselen' poblyzu sil Komarivka ta Ozarychi). Kyiv. [in Ukrainian].

Hrushevs'kyj, 1891 - Hrushevs'kyj, M. (1891). Ocherk istorii Kiyevskoy zemli ot smerti Yaroslava do kontsa XIV stoletiya. Kiev: Tip. Imperatorskogo Universiteta Sv. Vladimira V. I. Zavadskogo, 460-462. [in Russian].

Hrushevs'kyj, 1905 - Hrushevs'kyj, M. (1905). Istoriia Ukrainy-Rusy (Vol. 3). L'viv, 167-168, 170-172. [in Ukrainian].

Hrushevs'kyj, 1995 - Hrushevs'kyj, M. (1995). Istoriia Ukrainy-Rusy: v 11 t., 12 kn. (Vol. 6). Kyiv: Naukova dumka, (Pam'iatky istorychnoji dumky Ukrainy), 48. [in Ukrainian].

Ivanchenko, 1993 - Ivanchenko, L. (1993). Poros'ki kniazi. Starozhytnosti Pivdennoyi Rusi. Proceedings of the 3rd Historical and archeological Workshop "Chernihiv i yoho okruha v IX-XIII st.". Chernihiv, 105-107. [in Ukrainian]. 
Klepatskij, 2007 - Klepatskyj, P. (2007). Ocherky po istorii zemli Kievskoj: Litovskij peryod. Bila Tserkva: Vyd. O. V. Pshonkivs'kyj. [in Russian].

Korinnyj, 1992 - Korinnyj, N. (1992). Pereyaslavskaya zemlya: X - pervaya polovina XIII veka. Kiev. [in Russian].

Kozubovs'kyj, 1993 - Kozubovs'kyj, A. (1993). Kyivs'ke kniazivstvo pry Volodymyri Ol'herdovychi za pam'iatkamy numizmatyky. Starozhytnosti Pivdennoyi Rusi. Proceedings of the 3rd Historical and archeological Workshop "Chernihiv i yoho okruha v IX-XIII st.". Chernihiv, 131-136. [in Ukrainian].

Kozubovs'kyj, 2012a - Kozubovs'kyj, A. (2012). Dani numizmatyky pro torhivel'ni shlyakhy v Ukrayini v seredyni XIV st. Arkheolohiya, 3, 75-82. [in Ukrainian].

Kozubovs'kyj, 2012b - Kozubovs'kyj, A. (2012). Pereiaslavs'ka zemlia v XIV st. Istoryko-heohrafichni doslidzhennia v Ukraini. Zb. nauk. pr., 12, 96-109. [in Ukrainian].

Kozubovs'kyj, 2015 - Kozubovs'kyj, A. (2015). Pro deyaki ekonomichni naslidky pokhodiv Hedymina 20-kh rokiv XIV st. Arkheolohiya, 3, 33-43. [in Ukrainian].

Kozubovs'kyj, 2016 - Kozubovs'kyj, A. (2016). Do khronolohii karbuvannia monet Volodymyra Ol'herdovycha (1362-1394). Arkheolohiya, 4, 27-41. [in Ukrainian].

Kulakovs'kyj, 2015 - Kulakovs'kyj, P. (2015). Zvynyhorods'kyj povit u lytovs'ku dobu. Ukraina Lithuanica: studiyi z istoriyi Velykoho knyazivstva Lytovs'koho (Vol. 3.). Kyiv, 204-237. [in Ukrainian].

Kvitnyts'kyj, 2007 - Kvitnyts'kyj, M. (2007). Poros'ka zakhysna liniia: etapy formuvannia ta rozvytku (u svitli pysemnykh ta arkheolohichnykh dzherel). Mistse i znachennia Porossia v istorii Ukrainy (IX-XIII st.). (2007). Proceedings of the Scientific and Practical Conference. 28 lystopada 2007 r. Korsun'Shevchenkivs'kyj, 17-50. [in Ukrainian].

Lyubavskiy, 1892 - Lyubavskiy, M. (1892). Oblastnoye deleniye i mestnoye upravleniye Litovsko-Russkogo gosudarstva ko vremeni izdaniya pervogo Litovskogo statuta. Moskva, 235-248. [in Russian].

Lyubavskiy, 1915 - Lyubavskiy, M. (1915). Ocherk istorii Litovsko-Russkogo gosudarstva do Lyublinskoy unii vklyuchitel'no. Moskva, 95-102, 122-132. [in Russian].

Mistse i znachennia Porossia, 2007 - Mistse i znachennia Porossia v istorii Ukrainy (IX-XVII st.). (2007). Proceedings of the Scientific and Practical Conference. 28 lystopada 2007 r. Korsun'-Shevchenkivs'kyj. [in Ukrainian].

Mykhaylyuk, 2011 - Mykhaylyuk, Yu. (2011). Pivdenna Kyyivshchyna v 60-kh rr. XIV - 60-kh rr. XVI st.: derzhavne upravlinnya ta hromads'ke samovryaduvannya. Cherkasy: «Vertykal'». [in Ukrainian].

Pritsak, 1988 - Pritsak, O. (1988). The Pre-Ashkenazic Jews of Eastern Europe in Relation to the Khzars, the Rus' and the Lithuanians. Ukrainian-Jewish Relations in Historical Perspective. Edmonton, 1988, 14. [in English].

Rusyna, 1996 - Rusyna, O. (1996). Putyvl's'ki volosti XV - pochatku XVII st. Zapysky NTSH. (vol. 231.), L'viv, 367-378. [in Ukrainian]. 
Rusyna, 1998 - Rusyna, O. (1998). Ukraina pid tataramy i Lytvoyu. Kyiv, Vydavnychyy dim "Al'ternatyvy". [in Ukrainian].

Rusyna, 2005a - Rusyna, O. (2005). Putyvl's'ki volosti XV - pochatku XVII st. Studiyi z istoriyi Kyiva ta Kyivs'koyi zemli. Kyiv, 114-136. [in Ukrainian].

Rusyna, 2005b - Rusyna, O. (2005). Studiyi z istoriyi Kyiva ta Kyyivs'koyi zemli. Kyiv: Instytut istoriyi Ukrainy NAN Ukrainy. [in Ukrainian].

Rusyna, 2008 - Rusyna, O. (2008). Tatars'ka y lytovs'ka doba v istoriyi Ukrayiny. Politychna systema dlya Ukrainy: istorychnyy dosvid i vyk klyky suchasnosti. Kyiv: Nika-Tsentr, 57-82. [in Ukrainian].

Starozhytnosti Pivdennoyi Rusi, 1993 - Starozhytnosti Pivdennoyi Rusi. Proceedings of the 3rd Historical and archeological Workshop. (Chernihiv, 15-18 travnya 1990 r.). Chernihiv. [in Ukrainian].

Tereshchenko, 1996 - Tereshchenko, Yu. (1996). Ukraina i yevropeys'kyy svit: narys istoriyi vid utvorennya starokyyivs'koyi derzhavy do kintsi XVI st. Kyiv, 173. [in Ukrainian].

Tomashivs'kyy, 1919 - Tomashivs'kyy, S. (1919). Ukrayins'ka istoriya. Starynni i seredni viky. (pt. 1.). L'viv, 99. [in Ukrainian].

Veremejchyk, Kozubovs'kyy, 2016 - Veremeychyk, O., Kozubovs'kyy, A. Seredn'ovichnyy monetnyy skarb iz rozkopok Lyubecha. Arkheolohiya, 1, 64-69. [in Ukrainian].

Vladimirskiy-Budanov, 1911 - Vladimirskiy-Budanov, M. (1911). Zastavnoye vladeniye. Arkhiv Yugo-Zapadnoj Rossii. (pt.8/vol.6). Kiev, 52-53. [in Russian].

Yablonovskiy, 1896 - Yablonovskiy, A. (1896). Levoberezhnaya Ukraina v XVXVIII st. Kiyevskaya starina (Vol. LIII.), 85-101. [in Russian]. 